\author{
Fahni Haris ${ }^{1}$, Sri Yusrian ${ }^{1}$ \\ ${ }^{1}$ Universitas Muhammadiyah Yogyakarta \\ Corresponding Author: Fahni Haris \\ Email: hi_okt@yahoo.com
}

\section{Correlation of E-Learning Courses toward Nursing Students' Cognitive Skills}

$\begin{array}{ll}\text { Article Info } & \\ \text { Online } & : \text { http://journal.umy.ac.id/index.php/ijnp } \\ \text { ISSN } & : 25484249 \text { (Print) } \\ & : 2548 \text { 592X (Online) } \\ \text { DOI } & : 10.18196 / \text { ijnp.3298 }\end{array}$

\begin{abstract}
Background: E-learning is one of the new learning methods in the Indonesian education system. This system has been used to increase students' understanding levels. The researcher has noticed that students had a lack of cognitive level due to the misinterpretation and mis-extrapolation of the materials. E-learning shall improve students' cognitive level in courses. The researcher is interested in exploring the correlation between the effectiveness of online classes and nursing students' cognitive level.
\end{abstract}

Objective: This study aims to identify the relationship between the effectiveness of online courses through the e-learning system and students' understanding level at Universitas Muhammadiyah Yogyakarta.

Method: This study implemented a quantitative method with a crosssectional design along with The Pearson product-moment correlation to measure the correlation strength.

Results: The researcher found E-learning adequate to be applied to nursing students of Universitas Muhammadiyah Yogyakarta $185.8 \%$ out of total respondents, $N=288$ ). The average score of the seven components measured (productivity, quality, efficiency, flexibility, eminence, development, and satisfaction) was 68.54, while the average rating of students' cognitive level was 53.92.

Conclusion: There was a significant correlation between e-learning as an education system and nursing students' cognitive level.

Keywords: e-learning; cognitive; correlation; nursing student; understanding

\section{INTRODUCTION}

Science has become one of the main demands for world development, especially in the learning process. The high demand requires each educational institution to improve its quality. Currently, there is one perspective in a learning process regarding information and technology (IT), which is an e-learning system. E-learning as a learning system allows both students and teachers to perform the learning process through online activities. Regarding this matter, Supriadi (2017) argues that the online learning system (e-learning) is believed to be more effective than the traditional learning system, with the average scores of 84.04 and 74.28 , respectively.
The e-learning system already has the privileges that make it advantageous to be applied, especially in higher education. The first privilege is that IT is not only universal for all countries but also one of the interface products that are relatively easy to learn. The second privilege is that students are familiar with electronic devices to exchange information, and IT has become a part of many people's daily activities. As a result, informal education also has a vital role along with traditional and formal education. In this case, the young generation nowadays can independently gain various types of knowledge through technology and media, such as electronic media, mass media, e-books, 
encyclopedias, repository videos, even online courses, and open universities. The third privilege is that the modern world requires the fastest and cheapest ways to produce and distribute knowledge. The rapid growth of technology and education system initiates the electronic or online learning system, which is also known as e-learning, implemented in many countries to train the professionals in higher education (Yanuschika, Pakhomovaa, \& Batbolda, 2015).

Several factors influence the students' understanding level, and one of them is the learning method. Arifanti (2016) claims that not all learning methods are useful; thus, this matter will also influence the students' understanding level regarding the materials. As an example, the use of video as a learning tool has been argued to increase the interest, knowledge, and learning outcomes of the students, from 33.75/100 to become 78.25/100 (Abidin, Afidh, \& Mukhtar, 2015). Yanuschika, Pakhomovaa, \& Batbolda (2015) adds that through interactive videos in e-learning, the understanding level of students in Mathematics, as well as their ability to solve problems, are proven to increase. The results of the study conducted by (Cardoso et al., 2012), furthermore, affirms that students' cognitive levels and skills improve along with the available informative video in a learning platform named Moodle.

Other than the learning methods, the curriculum, tutors or teachers, moods of the students, and adequate learning resources influence the success of the e-learning system (Fandino, Munoz, \& Velandia, 2019). Based on the background elucidated beforehand, along with the suitable curriculum, lecturers, and proper learning resources in Universitas Muhammadiyah Yogyakarta, this study aims to discern the correlation between elearning and students' understanding level in Universitas Muhammadiyah Yogyakarta.

\section{METHOD}

This study applied a qualitative method with a crosssectional approach to identify the relationship between the independent and dependent variables by using a one-time measure at the same time (Sopiyudin, 2011). The researcher collected the data by distributing questionnaires to the students of Nursing School of the Faculty of Medicine and Health Sciences Universitas Muhammadiyah
Yogyakarta class of 2015, 2016, and 2017 as many as 288 people. The questionnaires were the instrument of the research and became the source of the primary data of this study. The instrument validity test carried out to 30 respondents obtained the $r$ coefficient from 0.372 to 0.775 , so that the reliability test by implementing Cronbach's alpha method obtained a score of $0.88(>0.70)$. The additional instrument used in this study was the questionnaire consisting of 30 statements developing seven components of online learning activities.

Meanwhile, the questionnaire regarding the comprehension level consisted of 3 development statements of 3 cognitive components, namely translation, interpretation, and extrapolation (Bloom, 1978: 90) cit (Harjanti, Ningrum, \& Yani, 2014). The data analysis used in this study was Pearson product-moment correlation to ascertain the average score of the components, effectivity, which was e-learning, and the average rating of students' understanding level (cognitive level).

\section{RESULTS}

1. E-learning in Universitas Muhammadiyah Yogyakarta

Table 1. The Results of the Respondents' Responses on the Seven Components of ELearning

\begin{tabular}{lc}
\hline \multicolumn{1}{c}{ Component } & Average \\
\hline Productivity & 73.02 \\
Quality & 68.46 \\
Efficiency & 69.11 \\
Flexibility & 73.66 \\
Eminence & 67.84 \\
Development & 70.78 \\
Satisfaction & 59.49 \\
\hline
\end{tabular}

From Table 1, the seven components indicating the effectivity of e-learning in the Nursing School in Universitas Muhammadiyah Yogyakarta is in the range value of 59.49 to 73.66 .

Table 2. The Average of the Seven Components of E-Learning

\begin{tabular}{cccccc}
\hline Mean & Median & Mode & Min & Max & $\begin{array}{c}\text { Standard } \\
\text { Deviation }\end{array}$ \\
\hline 68.54 & 68.33 & 68.33 & $\begin{array}{c}25.8 \\
3\end{array}$ & $\begin{array}{c}89.1 \\
7\end{array}$ & 7.342 \\
\hline
\end{tabular}




\section{NUNRSERING \\ PRACTICES}

Table 2 denotes that the highest score of the seven components of e-learning is 89.17 , while the lowest score is 25.83 , with an average score of 68.54 .

2. Understanding the Level of Universitas Muhammadiyah Yogyakarta's Students

Table 3. The Results of the Respondents' Responses on Each Category of Understanding after Completing E-Learning

\begin{tabular}{lc}
\hline Category & Average \\
\hline Translation & 56.86 \\
Interpretation & 48.03 \\
Extrapolation & 51.73 \\
\hline
\end{tabular}

Table 3 displays three categories of the understanding level measured; the average scores obtained are in the range of 48.03 until 56.86 .

Table 4. Students' Understanding Level after Completing E-Learning

\begin{tabular}{cccccc}
\hline Mean & Median & Mode & Min & Max & $\begin{array}{c}\text { Standard } \\
\text { Deviation }\end{array}$ \\
\hline 53.92 & 56.25 & 50.00 & 6.25 & 93.75 & 17.309 \\
\hline
\end{tabular}

From Table 4, the highest score for the understanding level is 93.75 . The lowest score is 6.25 , with an average score of 53.92 .

3. The Relationship between E-Learning and Students' Understanding Level in Universitas Muhammadiyah Yogyakarta

Tabel 5. The Distribution of the Correlation between E-Learning and Students' Understanding Level in Universitas Muhammadiyah Yogyakarta

\begin{tabular}{cccccccc}
\hline Variable & Mean & Median & Mode & Min & Max & St dev. & $p$-value \\
\hline E-learning & 68.54 & 68.33 & 68.33 & 25.83 & 89.17 & 7.342 & \multirow{2}{*}{0.000} \\
Understanding level & 53.92 & 56.25 & 50.00 & 6.25 & 93.75 & 17.309 & \\
\hline
\end{tabular}

Table 5 presents that the $p$-value obtained from both variables is $0.00 \quad(p<0.05)$, which implies, statistically, a correlation between e-learning and the students' understanding level.

\section{ANALYSIS}

The Correlation between E-Learning and Students' Understanding Level

Understanding level, particularly in this study, is influenced by several factors, for instance, students' interests and learning methods that are suitable for students from higher education. This statement is in line with a study conducted by Arifanti (2016). She concludes that students' understanding level could be affected by the effectivity factors of the learning methods as well as the interests for learning. The learning method applied, in this case, is the one used for adult learners performed through online media, such as a website.

\section{DISCUSSION}

Based on the analysis completed to the obtained data, the researcher can argue that the implementation of the e-learning system to the nursing students of the Faculty of Medicine and
Health Sciences Universitas Muhammadiyah Yogyakarta is noticeably effective. The effectiveness of the e-learning system, moreover, is influenced by several components, such as productivity, quality, efficiency, flexibility, eminence, development, and satisfaction levels of the students. The results of the analysis regarding this matter, additionally, can be decided as useful since the display, features, contents, and the natural use of the e-learning system increase the participation of the students during the learning process, seen from the mean score on the productivity of the e-learning, which is as much as 73.02. This result is similar to the research completed by Alimron (2019) and Suartama (2013). They infer that the completeness and suitability of the contents of the e-learning system are essential in improving the learning process. Attractive display of the e-learning system, additionally, also contributes to rising students' interests to participate more actively during the learning process (Saifuddin, 2018).

The e-learning system analyzed in this study can also be said as qualified with the mean score of 68.48 , given the implementation of the system can be adjusted to the learning ability of the students. The 
smooth operation of the system also takes part in helping the students to optimize their learning ability. The research conducted by Amaliyah (2017) and Octavia (2017) complemented this study in the sense that the higher the level of the learning ability is, the more optimum the thinking and learning processes are. The different learning ability influences the learning capability. The learning ability, however, is also affected by the excellent and qualified learning methods (Andartari, Susanti, \& Andriani, 2013). The secure navigation system in e-learning, particularly on the matter of presenting learning materials, eases the students to obtain more knowledge and to understand and comprehend the learning materials uploaded in the system (Abdulmajid, \& Pramuntadi, 2017; Sulisworo \& Agustin, 2017).

The results of the analysis on the efficiency level of the e-learning system generated the mean as much as 69.11 , implying that the operation can be utilized at any time by the students. This result is in line with the results of the research piloted by Wahyuni \& Halili (2017) and Sefrika (2018). Both pieces of research denoted that through the e-learning system, students, especially university students, could also conveniently study outside the school at any time, effectively and efficiently. The availability of the learning materials that are accessible every time and everywhere in the e-learning system is believed helping the students to study better and getting a better grade (Dewi, 2018).

Regarding the flexibility of the e-learning system, the results indicated that the e-learning as the system applied had functioned effectively, with the mean score of 73.66, given the fact that it was within reach. The flexibility of the system, furthermore, was proven to help students in recalling the learning materials in the form of video or other media. The result of the flexibility of the e-learning system in this study is similar to the research carried out by Cahyono (2015). He affirms that the enactment of elearning motivates the students to study more in their free time. Its flexibility is visible through how easy it is to use at any place with an internet connection (Cahyono, 2015).

The e-learning system assessed in this study obtained the mean score of 67.84 at the matter of its eminence that, according to the users, e-learning could facilitate the teachers to achieve the learning objectives and to give the students feedback as a control of the students' performances. By utilizing elearning, the students are aware that the teachers can easily keep track of their learning performances. Abidin et al. (2015), in their research, have affirmed that feedbacks or suggestions from the teachers, along with small quizzes given to the students, also play essential roles during the learning process. Cahyono (2015) suggests that further explanation or responses given by teachers are endeavors in keeping track of the students' learning performances during the learning process.

The obtained mean score of 70.78 is after analyzing the development level of the e-learning system as the object of this study, which denotes the welldeveloped system. Proper development of the elearning system creates complete learning activities for the students, such as discussion forums and quizzes, to increase the understanding level and as a form of evaluation of how well the students comprehend the materials after carrying out online learning. Regarding this matter, Niswati, Donna, Lestari, \& Gustyani (2017); Hakim (2018) agree that discussion forums included in the e-learning system might provide an opportunity for the students to give feedback and opinions on specific learning topics. Quizzes, on the other hand, are believed as a way to develop learning activities, primarily through the e-learning system, as an evaluation of student learning outcomes (Cahyono, 2015).

The result of the analysis regarding the students' satisfaction level on the e-learning system is still fair, proven by the mean score that is as much as 59.49 . Most students find it challenging to access the system and continue the learning process due to unstable and weak internet connection. Supriadi (2017) and Niswati, Donna, Lestari, \& Gustyani (2017) argued that poor internet connection is the biggest obstacle for the students to carry out online learning. Thus, a stable internet connection, indeed, is indispensable in supporting the online learning process (Priantama, 2015). Riyanto (2014) added that a stable internet connection could help students to get more information needed as part of the learning process.

After carrying out the analysis, the students' understanding level in the learning process by utilizing the e-learning system is at a moderate level, with a mean score of 56.86 . This score denotes that after completing online learning through the e- 


\section{NURSEING \\ PRACTICES}

learning system, the students are familiar with the topic, material, and content of the course given. The appropriate understanding level might be because of the new learning system that attracts the students. The result of this analysis is in line with the results of the research conducted by Karwati (2014), Nasution (2017) and Khoirunnisa et al., (2018) which concluded that discussion forums and provided learning materials in e-learning system helped the students to get more knowledge and to increase their understanding level. The submitted materials, furthermore, are accessible at any time and any place that can ease the students to review and deepen their understanding upon them (Karwati, 2014; Nasution, 2017). The discussion forum as a feature in the e-learning system has become one of the platforms for students to discuss things regarding the upcoming learning materials (Kurniawan, Suprianto, and Sumardiyono, 2016; Sinaga, 2015; Khoirunnisa et al., 2018).

The interpretation of the students on this online system is inadequate, seen from the mean score of 48.03. The result of the analysis indicates that a lack of learning-support factors and a lack of feedback or explanations from the teachers might cause a low level of interpretation. Oetary (2017) dan Utomo dan Imron (2017) suggested that several factors may increase students' understanding level, such as the implementation of sufficient and complete learning media as well as a thorough explanation from the teachers. Lack of learning support factors, namely unhealthy learning environment, unsupportive learning tools, for example, laptop or mobile phone, and troublesome internet connection may affect the success learning level of the students (Oetary, 2017).

The mean score of 51.73 indicated that the students' extrapolation on the e-learning system is still weak. Extrapolation itself can be described as the students' ability to make summaries, descriptions, and conclude the learning materials learned through the e-learning system. The low score of students' extrapolations can also have connections to the students' translation and interpretation abilities. Suhendar dan Ekayanti (2018) claimed that the success of the students to understand the learning materials is inseparable from the level of knowledge and the ability to analyze and comprehend the methods and materials during the learning process. The exposure of the learning materials as well as the discussion forums, if well-benefitted, can be helpful for the students to increase their understanding of certain materials. The students' habit, however, also needs to be taken seriously in noticing how students take advantage of the e-learning system to enhance their learning process (Karwati, 2014; Khoirunnisa et al., 2018; Kurniawan et al., 2016; Nasution, 2017; Sinaga, 2015).

The supporting factors of the learning process that have been described beforehand are also indispensable in increasing the students' understanding level. The obstacle to using the elearning system, such as poor internet connection, is believed as an obstacle for the students to increase their level of understanding (Oetary, 2017; Priantama, 2015; Riyanto, 2014; Sinaga, 2015). Further explanation of the learning materials by the teachers, on the other hand, becomes another essential role in the learning process caused by the fact that the presence of the teacher during the learning process can be useful to take notes on the students' development as well as to explain the materials deeper should the students have questions to deepen their understanding level (Abidin et al., 2015; Niswati, Donna, Lestari, \& Gustyani (2017); Utomo \& Imron, 2017).

\section{CONCLUSION}

Based on the analysis of the data elucidated, there is a correlation between online learning through the e-learning system and the students' understanding level

\section{REFERENCES}

Abdulmajid, N. W., Pramuntadi, A., Riyanto, A. B., \& Rochmah, E. (2017). Penerapan E-Learning Sebagai Pendukung Adaptive Learning dan Peningkatan Kompetensi Siswa SMK di Kabupaten Bantul. Taman Vokasi, 5(2), 170182.

Abidin, Afidh, \& Mukhtar. (2015). Pengembangan Konten e-Learning Universitas Syiah Kuala untuk Pembelajaran: Modul e-Learning: Universitas Syiah Kuala. 
Alimron, A. (2019). Penerapan E-Learning dalam Proses Pembelajaran pada Program Studi PAI Universitas Islam Negeri Raden Fatah Palembang. Hayula: Indonesian Journal of Multidisciplinary Islamic Studies, 3(1), 105120. https://doi.org/10.21009/003.1.06

Amaliyah. (2017). Hubungan Kecerdasan Intelektual dan Kecerdasan Emosional Dengan Prestasi Belajar Siswa SD Muhammadiyah 29 Sunggal Deli Serdang. Jurnal ANSIRU, 1(1), 64-87.

Andartari, S. S., \& Andriani, V. (2013). Pengaruh Kemampuan Intelektual (IQ) dan Motivasi Belajar terhadap Hasil Belajar Siswa pada Mata Pelajaran Akuntansi pada SMA Labschool Rawamangun. Jurnal Pendidikan Ekonomi Dan Bisnis, 1(1), 1-24.

Arifanti, R. (2016). Faktor-Faktor Yang Mempengaruhi Pemahaman Mahasiswa Akuntansi Terhadap Makna Aset, Kewajiban dan Ekuitas. Jurnal Akuntansi Dan Ekonomi Bisnis, 5(1), 45-57.

Cahyono, Y. D. (2015). E-Learning (EDMODO) Sebagai Media Pembelajaran Sejarah. Jurnal Penelitian, 18(2), 102-112.

Cardoso, A. F., Moreli, L., Braga, F. T., Vasques, C. I., Santos, C. B., \& Carvalho, E. C. (2012). Effect of a video on developing skills in undergraduate nursing students for the management of totally implantable central venous access ports. Nurse education today, 32(6), 709-713.

Dewi, E. R. (2018). Metode Pembelajaran Modern dan Konvensional pada Sekolah Menengah Atas. PEMBELAJAR: Jurnal IImu Pendidikan, Keguruan, dan Pembelajaran, 2(1), 44-52.

Fandiño, F. G. E., Muñoz, L. D., \& Velandia, A. J. S. (2019). Motivation and E-Learning English as a foreign language: A qualitative study. Heliyon, 5(9), e02394.

Hakim, A. R. (2018). Pengembangan E-Learning Berbasis Moodle Sebagai Media Pengelolaan Pembelajaran. Kodifikasia, 12(2), 17, 167-183.
Harjanti, D. T. Penerapan Teknik Peta Pikiran (Mind Map) untuk Meningkatkan Pemahaman Konsep Geografi pada Peserta Didik Kelas XI-2 IPS SMAN 1 Rasau Jaya Kabupaten Kubu Raya. Jurnal Geografi Gea, 14(1). 94-100

Karwati, E. (2014). Pengaruh Pembelajaran Elektronik (E-Learning) Terhadap Mutu Belajar Mahasiswa. Jurnal Penelitian Komunikasi, 17(1), 41-54. https://doi.org/10.20422/jpk.v17i1.5

Khoirunnisa, R. N., Dewi, D. K., \& Nurwidawati, D. (2018). Pembelajaran E-Learning Perkembangan Anak di Jurusan Psikologi. Jurnal Psikologi Teori dan Terapan, 9(1), 6276.

Kurniawan, W., Suprianto, A., \& Sumardiyono, B. (2016). Rancangan Sistem Forum Diskusi Online Untuk Program Studi Sistem Informasi Antara Dosen Dan Mahasiswa. Rekayasa Informasi, 5(2), 43-51.

Nasution, M. K. (2018). Penggunaan Metode Pembelajaran Dalam Peningkatan Hasil Belajar Siswa. Studia Didaktika, 11(1), 9-16.

Niswati, I., Donna, A. K., Lestari, P., \& Gustyani, G. (2017). Hubungan Antara Metode Online Learning (E-Learning) dengan Motivasi Berprestasi Mahasiswa Universitas "XX". Psibernetika, 5(1), 23-39.

Octavia, V. C., Sulisetijono, \& Masjhudi. (2017). Hubungan Intelligence Quotient (IQ) Dengan Hasil Belajar Kompetensi Kognitif Siswa Kelas XI IPA SMAK Santa Maria Malang Pada Bentuk Soal Objektif dan Uraian. Skripsi Universitas Negeri Malang

Oetary, N. (2018). Faktor-faktor yang Mempengaruhi Keberhasilan Dan Kegagalan Mahasiswa Akuntansi Dalam Mata Kuliah Pengantar Akuntansi (Studi Empiris pada Mahasiswa Akuntansi S1 di Fakultas Ekonomi Universitas Negeri Padang). Jurnal Akuntansi, 6(1), 1-32.

Priantama, R. (2017). Efektivitas Wifi Dalam Menunjang Proses Pendidikan Bagi Lembaga Perguruan Tinggi (Studi Kasus Terhadap Mahasiswa Pengguna Di 


\section{NURSTING \\ PRACTICES}

Lingkungan Universitas Kuningan). Cloud Information, 1(1), 22-28.

Riyanto. (2014). Pemanfaatan Internet dan Motivasi Belajar Terjadap Prestasi Belajar Siswa Kelas $X$ (Studi Kasus Pada Kompetensi Keahlian Elektronika Industri di SMK Muda Patria Kalasan). Skripsi FT Universitas Negeri Yogyakarta.

Saifuddin, M. F. (2018). E-learning dalam persepsi mahasiswa. Jurnal VARIDIKA, 29(2), 102109.https://doi.org/10.23917/varidika.v29i 2.5637

Sefrika. (2018). Analisa Penerimaan Teknologi ELearning PADAAMIK BSI Jakarta. Journal of Informatic Pelita Nusantara, 3(1).

Sinaga, B. (2015). Perancangan dan Pembuatan Sistem Informasi Forum Diskusi Mahasiswa/i Berbasis Web di STMIK Pelita Nusantara Medan. Jurnal Mantik Penusa, 18(2).

Sopiyudin, M.D., (2011). Statistik untuk Kedokteran dan Kesehatan: Deskriptif,. Bivariat, dan Multivariat. Edisi 5. Jakarta : Salemba Medika.

Suartama, I. K. (2013). Edutech Smart: Sebuah Pengembangan Portal E-Learning untuk Meningkatkan E-fektivitas Pembelajaran. Jurnal Pendidikan dan Pengajaran, 46(3), 218-227.

Suhendar, U., \& Ekayanti, A. (2018). Problem Based Learning Sebagai Upaya Peningkatan Pemahaman Konsep Matematis Mahasiswa.
Jurnal Dimensi Pendidikan dan Pembelajaran, 6(1), 15-19.

Sulisworo, D., \& Agustin, S. P. (2017). Dampak Pembelajaran E-Learning Terhadap Motivasi Pada Pembelajaran Fisika Di Sekolah Kejuruan. Berkala Fisika Indonesia, 9(1), 3-6. Supriadi, F. (2017). Efektivitas Pembelajaran Media E- Learning Berbasis Web Dan Konvensional Terhadap Tingkat Keberhasilan Belajar Mahasiswa (Studi Kasus Mahasiswa Program Studi Manajemen Fakultas Ekonomi Universitas Muhammadiyah Pontianak. Jurnal Manajemen Motivasi, 12(2), 722-726. https://doi.org/10.29406/jmm.v12i2.449

Utomo, A. A., Imron, A., \& Syaiful, M. (2017). Pengaruh Penjelasan Guru terhadap Pemahaman Siswa pada Mata Pelajaran Sejarah. PESAGI (Jurnal Pendidikan dan Penelitian Sejarah), 5(8).

Wahyuni, Y. T. (2017). The Implementation of ELearning on the Subject of Pendidikan Pancasila dan Kewarganegaraan of XI Class In SMA Negeri 1 Yogyakarta. E-Civics, 6(3), 419-430.

Yanuschika, O. V., Pakhomovaa, E. G., \& Batbolda, K. (2015). E-learning as a Way to Improve the Quality of Educational for International Students. Procedia - Social and Behavioral Sciences 215, 147- 155. 